\title{
Antimicrobial Properties of Bamboo Fibres
}

\author{
N Gokarneshan ${ }^{1}$, and Anish khan ${ }^{2}$ \\ ${ }^{1}$ Department of costume design and fashion, SNS Rajalakshmi college of arts and science, India \\ ${ }^{2}$ Chemistry department, Faculty of science, King Abdulaziz University, Saudi Arabia
}

*Corresponding author: N Gokarneshan, Department of costume design and fashion, SNS Rajalakshmi college of arts and science, Coimbatore, India

\begin{tabular}{|c|c|}
\hline ARTICLE INFO & ABSTRACT \\
\hline Received: December 12, 2020 & \multirow{5}{*}{$\begin{array}{l}\text { The article reviews some significant recent research in development antimicrobial } \\
\text { textiles using bamboo fibres. Study was conducted with } 12 \text { commercial bamboo } \\
\text { viscose, conventional rayon, cotton fibers, } 4 \text { bamboo species and } 12 \text { Natural Bamboo } \\
\text { Fiber (NBF) samples to test antibacterial activity against Staphylococcus aureus and } \\
\text { Klebsiella pneumoniae. The accuracy and efficacy of test methods were investigated } \\
\text { and modified for antibacterial assessment. While the spectrophotometric method was } \\
\text { found to be less effective due to low bacterial reduction, the revised viable plate counting } \\
\text { technique was consistent and effective for samples in fabric, fiber or powder form. The } \\
\text { antibacterial activity of moso bamboo shoot skin (Phyllostachys pubescens). The nature } \\
\text { of antibacterial property of natural bamboo fiber was determined with the method of } \\
\text { dynamic test and compared with other fibers for textile, such as jute fiber, flax fiber, ramie } \\
\text { fiber and regenerated bamboo fiber. The bacteria used in the test were Escherichia coli, } \\
\text { Staphylococeus auresu and Candida albican. }\end{array}$} \\
\hline Published: December 23, 2020 & \\
\hline $\begin{array}{l}\text { Citation: N Gokarneshan, Anish khan. } \\
\text { Antimicrobial Properties of Bamboo } \\
\text { Fibres. Biomed J Sci \& Tech Res 32(5)- } \\
\text { 2020. BJSTR. MS.ID.005309. }\end{array}$ & \\
\hline $\begin{array}{l}\text { Keywords: Antibacterial activity; Bamboo } \\
\text { fibre; Staphylococcus Aureus; Bamboo }\end{array}$ & \\
\hline Viscose Textiles; Influencing Factors & \\
\hline
\end{tabular}

\section{Introduction}

With the advancement of textile technology, the uses of textiles are not limited to apparel, clothing, coverings, or protection against the weather. Technical textiles such as medical textiles, geotextiles, and smart textiles are being developed for specialized uses. Textiles because of their nature are ideal substrates for providing antibacterial properties. Currently, textiles and apparel with antibacterial/antimicrobial, antifungal and anti-mildew properties are very important for use in medical clothing, therapeutic clothing, wound healing, and protective clothing as well as regular daily use. The necessity and demand for such products has led to novation and development of antibacterial textiles [1-17]. Accordingly, the research and the production of antibacterial textiles has grown to help meet the demand [18]. Properties can be developed in the products by special treatment during dyeing, wet processing, finishing or other process stages [19-24]. A challenge has been to develop chemical compounds that can provide antibacterial activity in industrial processing, as currently, they can be toxic and harmful to the human body and health [25]. In contrast, natural compounds that provide antibacterial properties are considered more humanfriendly. Consequently, there are numerous efforts to develop antibacterial properties from natural materials and processes, such as natural antibacterial activity from plants or microorganisms in fibers, pigments or dyes. Moreover, if a material has natural antibacterial activity it could prove more durable as part of the material that would not wash away as opposed to artificially added antibacterial compounds.

As an abundant resource in China and an eco-friendly and multifunctional plant, bamboo has been used in architecture, agriculture, furniture and paper-making for thousands of years. Recently, research on producing textile fiber from bamboo has been conducted. According to different preparation techniques, the bamboo fiber for textile has been divided into two kinds, natural bamboo fiber and regenerated bamboo fiber [26]. The natural bamboo is usually in the form of fiber bundle which is produced by unique chemical and physical technique $[27,28]$. The regenerated bamboo fiber is made from bamboo pulp, which has a similar processing method to the ordinary viscose fiber [29].

\section{Comparative Studies on Bamboo Plants, Bamboo Fibres and Commercial Bamboo Viscose Textiles}

Interestingly, bamboo has been reported as naturally antibacterial and this property is expected to be retained if the fibers are extracted in their natural form along with some nonfibrous trace elements. Since most of the existing natural and 
synthetic fibers do not have antibacterial activity, but rather some promote bacteria growth, extraction of NBFs with such activity is of great interest. Studies have concluded that extracts from bamboo leaves have shown antibacterial activity against some bacteria [30]. The inhibition of extract from Moso bamboo shoot skins against Staphylococcus aureus has been studied and reported that it exhibited antibacterial activity [15]. Moreover, different parts of bamboo plants (roots, leaves, skins) have already been used for manufacturing preservatives and medicinal products [31-35]. These studies on multiple bamboo species confirmed that the plants possess antibacterial activity. It was also shown that bamboo culms exhibited very high antibacterial property and fibers are mainly extracted from the culms. Therefore, it can be proposed that natural fibers from bamboo have the potential to retain antibacterial compounds, for example, phenolic compounds and lipids, and thus antibacterial properties [36]. Some studies have indicated that NBFs extracted from bamboo will have antibacterial properties [37-41].

To test the antibacterial property of natural fibers or plants, it is important to have suitable methods that can be conducted appropriately to assess even when the activity is very low. Since the zone of inhibition technique is not suitable and not highly precise for non-fabric specimens, this study was conducted on spectrophotometric and viable plate counting techniques to assess the antibacterial property of different types of specimens. Since the natural bacterial inhibition/reduction of the fibers is generally not very high and thus the change in Optical Density (OD) is very low, the spectrophotometric technique was found to be unsuitable for such tests [42]. The viable plate counting was revealed to be very suitable for almost all types of samples such as fabrics, fibers, and crushed raw bamboo samples. Results were found to be consistent and repeatable if conducted properly. Sterilization of the samples before the experiment is recommended as any contaminating bacteria is eliminated. A longer period can be allowed to provide more time for growth for slow-growing bacteria for better counting precision. The percentage reduction of bacteria by bamboo viscose textiles was tested where antibacterial activity was found in only one out of 12 products. This provides an understanding that antibacterial properties by bamboo viscose may not be a property from the bamboo, rather it comes from special treatments or through processing chemicals. Without these additional treatments, products from bamboo viscose would not offer bacterial protection. On the other hand, microscopic images revealed that there were some non-fibrous elements with Natural Bamboo Fibers (NBFs) of four bamboo species. All four bamboo species and their NBFs exhibited antibacterial activity to a certain degree. The activity was stronger against K. Pneumoniae than against S. Aureus. Results also suggested that though raw bamboo has antibacterial compounds, it may have bacteria-promoting substances at the same time that caused higher growth of bacteria if non-sterilized samples were tested. The bacterial inhibition was higher for sterilized bamboo and NBF samples. Thus, due to the presence of bacteria from the environment, some NBF specimens showed a greater number of colonies and a negative reduction of bacteria when sterilization of the fiber specimens was not performed prior to the experiment protocol. Further investigations are needed to establish this technique in textile materials and to confirm if bamboo species and its NBFs have antibacterial activity and such activity is not contributed by processing chemicals. Moreover, the antibacterial property of such materials needs to be tested against other bacteria species.

\section{Factors Influencing Antibacterial Properties of Bamboo Fibres}

Clothing manufactured by regenerated bamboo fiber has entered the textile market with a claim for its antimicrobial property, but without scientific evidence [43]. With the success of the separation techniques of natural bamboo fiber, people start to pay attention to the antibacterial property of natural bamboo fiber. However, there are different opinions on this issue. High bactericidal rate of natural bamboo fiber against some kinds of bacteria has been reported and the antibacterial agent in bamboo fiber has been identified as anthraquinone compounds that contain four $\alpha$-hydroxylation functional groups $[44,45]$. However, results released from other studies have indicated that natural bamboo fiber has no significant antibacterial effect ( Zhou Hengshu and Deng Libin. 2005) and even if it does, it is just because of certain natural micro-structure, not the antibacterial constituents [46,47]. The aim of this paper was to investigate the natural antibacterial property of natural bamboo fiber and its influencing factors. As cotton, jute, flax and ramie are also plant fiber being used in textiles, they were selected to be compared with natural bamboo fiber. Meanwhile, the antibacterial property of regenerated bamboo fiber was also evaluated and compared with natural bamboo fiber. In this study, the antibacterial property of natural bamboo fiber and its influencing factors were investigated. The antibacterial test results show that natural bamboo fiber has no natural antibacterial property compared with other textile fiber [48]. The fact that the growth of bacteria on different shapes of bamboo was nearly equal may indicate that the shape could not impact the antibacterial activity of natural bamboo fiber. The linear relationship between the moisture regain and the bacteriostatic rate suggests that the hygroscopicity may be a influencing factor in antibacterial performance of fiber. Some extraction method could improve the antibacterial property of natural bamboo fiber against bacteria, therefore, extractives have influence on that.

\section{Conclusion}

Results revealed that only one viscose product showed antibacterial activity but the majority of the specimens from bamboo plant species and NBFs showed a quantifiable percentage reduction of bacteria against K. Pneumoniae (8-95\%) but had 
more modest results against $S$. Aureus $(3-50 \%)$. As the quantity of bacteria promoting compounds is lower than bacteria-killing compounds due to processing; NBFs showed higher reductions of bacteria than raw bamboo specimens. The relationships between the antibacterial property of natural bamboo fiber and its shape, hygroscopicity and extractives were tested to analyze the influencing factors. In the results, compared with natural cotton the bacteriostatic rates of natural bamboo fiber against the bacteria were all zero; that of jute fiber and flax fiber against ATCC10231 were $48 \%$ and $8.7 \%$; that of ramie fiber against ATCC 6538 was as high as $90.2 \%$; that of regenerated bamboo fiber against ATCC6538 was higher than $70 \%$. The bacteriostatic rates of the bamboo with different shape were all zero, that of plant fibers was inversely proportional to their moisture regain and the bacteriostatic action against ATCC 10231 of natural bamboo fiber extracted was lower, however, that against 8099, and ATCC 6538 was stronger except extracted with benzene. The results show that natural bamboo fiber has no natural antibacterial property. The shape could not impact the natural antibacterial property of natural bamboo fiber but the hygroscopicity and extractives have influence on that.

\section{References}

1. Abdel Mohsen AM, Hrdina R, Burgert L, Abdel Rahman RM, Hasova M (2013) Antibacterial activity and cell viability of hyaluronan fiber with silver nanoparticles. Carbohydrate Polymers 92(2): 1177-1187.

2. Boothroyd SCB, Mc Carthy BJ (2011) Antimicrobial treatments of textiles for hygiene and infection control applications: An industrial perspective. In Textiles for hygiene and infection control Woodhead Publishing pp. 196-209.

3. Budama L, Cakir BA, Topel EO, Hoda N (2013) A new strategy for producing antibacterial textile surfaces using silver nanoparticles. Chemical Engineering Journal 228: 489-495.

4. Cheng X, Ma K, Li R, Ren X, Huang TS (2014) Antimicrobial coating of modified chitosan onto cotton fabrics. Applied Surface Science 309: 138143.

5. Cheng X, Ma K, Li R, Ren X, Huang TS (2014) Antimicrobial coating of modified chitosan onto cotton fabrics. Applied Surface Science 309: 138143.

6. Chung YS, Lee KK, Kim JW (1998) Durable press and antimicrobial finishing of cotton fabrics with a citric acid and chitosan treatment. Textile Research Journal 68(10): 772-775.

7. Comlekcioglu N, Aygan A, Kutlu M, Kocabas YZ (2017) Antimicrobial activities of some natural dyes and dyed wool Yarn. Iranian Journal of Chemistry and Chemical Engineering 36(4): 137-144.

8. Gokarneshan N, Nagarajan V, Viswanath S (2018) Developments in antimicrobial textiles - some insights on current research trends. Biomedical Journal of Scientific \& Technical Research 8(3): 230-234.

9. Ibrahim NA, El Zairy WM, El Zairy MR, Eid BM, Ghazal HA (2011) A smart approach for enhancing dyeing and functional finishing properties of cotton cellulose/polyamide- 6 fabric blend. Carbohydrate Polymers 83(3): 1068-1074.

10. Ma M, Sun Y, Sun G (2003) Antimicrobial cationic dyes: Part 1: Synthesis and characterization. Dyes and Pigments 58(1): 27-35.

11. Prusty AK, Das T, Nayak A, Das NB (2010) Colourimetric analysis and antimicrobial study of natural dyes and dyed silk. Journal of Cleaner Production 18(16-17): 1750-1756.
12. Ren Y, Gong J, Fu R, Li Z, Yu Z (2017) Dyeing and functional properties of polyester fabric dyed with prodigiosins nanomicelles produced by microbial fermentation. Journal of Cleaner Production 148: 375-385.

13. Shahid M, Ahmad A, Yusuf M, Khan MI, Khan SA (2012) Dyeing, fastness and antimicrobial properties of woolen yarns dyed with gallnut. Dyes and Pigments 95(1): 53-61

14. Simoncic B, Tomsic B (2010) Structures of novel antimicrobial agents for textiles-a review. Textile Research Journal 80(16): 1721-1737.

15. Tanaka A, Kim HJ, Oda S, Shimizu K, Kondo R (2011) Antibacterial activity of moso bamboo shoot skin (Phyllostachys pubescens) against Staphylococcus aureus. Journal of Wood Science 57(6): 542-544.

16. Vroman I, Tighzert L (2009) Biodegradable polymers. Materials 2(2): 307-344.

17. Williams JF, Suess JC, Cooper MM, Santiago JI, Chen TY (2006) Antimicrobial functionality of healthcare textiles: Current needs, options, and characterization of $\mathrm{N}$ halamine based finishes. Research Journal of Textile and Apparel 10(4): 1-12.

18. Gupta D, Bhaumik S (2007) Antimicrobial treatments for textiles. Indian Journal of Fibre \& Textile Research 32(6): 254-263.

19. Bhuiyan MAR, Hossain MA, Zakaria M, Islam MN, Uddin MZ (2017) Chitosan coated cotton fiber: Physical and antimicrobial properties for apparel use. Journal of Polymers and the Environment 25(2): 334-342.

20. Manickam P, Thilagavathi G (2015) A natural fungal extract for improving dyeability and antibacterial activity of silk fabric. Journal of Industrial Textiles 44(5): 769-780.

21. Morais DS, Guedes RM, Lopes MA (2016) Antimicrobial approaches for textiles: From research to market. Materials 9(6): 498.

22. Patel BH, Tandel MG (2005) Antimicrobial finishing for textiles: An overview. Asian Dyer pp. 31-36.

23. Shalini D, Anitha G (2016) A review: Antimicrobial property of textiles. International Journal of Science and Research (IJSR) 5(10): 766-768.

24. Zhang Z, Chen L, Ji J, Huang Y, Chen D (2003) Antibacterial properties of cotton fabrics treated with chitosan. Textile Research Journal 73(12): 1103-1106.

25. Budama L, Cakir BA, Topel €0, Hoda N (2013) A new strategy for producing antibacterial textile surfaces using silver nanoparticles. Chemical Engineering Journal 228: 489-495.

26. Li Qingchun (2003) The Properties of Bamboo Fiber and Key Technology in Development. Sichuan Textile Sci Technol 5: 56-58.

27. Wang Chunhong, Wang Rui, Zhu Ruoying (2005) Producing Process of Bamboo Fiber. J Tianjin Polytechnic Univ. 24(4): 16-17.

28. Zhang Wei, Li Wenbin, Yao Wenbin (2007) Separating Mechanism of Long Bamboo Fiber and Production Method. J Beijing Forestry Univ 29(4): 63-66.

29. Zhou Hengshu ,Zhong Wenyan (2003) Development and Application of Bamboo Fiber. Wool Textile J (4): 30-36.

30. Singh V, Shukla R, Satish V, Kumar S, Gupta S (2019) Antibacterial activity of leaves of BAMBO0. International Journal of Pharma and Bio Sciences $9(3): 1-5$.

31. Keski Saari S, Ossipov V, Julkunen Tiitto R, Jia J, Danell K (2008) Phenolics from the culms of five bamboo species in the Tangjiahe and Wolong Giant Panda Reserves, Sichuan, China. Biochemical Systematics and Ecology 36(10): 758-765.

32. Nirmala C, Bisht M S, Laishram M (2014) Bioactive compounds in bamboo shoots: Health benefits and prospects for developing functional foods. International Journal of Food Science \& Technology 49(6): 14251431. 
33. Quitain AT, Katoh S, Moriyoshi T (2004) Isolation of antimicrobials and antioxidants from Moso-Bamboo (Phyllostachys heterocycla) by supercritical $\mathrm{CO}_{2}$ extraction and subsequent hydrothermal treatment of the residues. Industrial \& Engineering Chemistry Research 43(4): 10561060

34. Tanaka A, Shimizu K, Kondo R (2013) Antibacterial compounds from shoot skins of moso bamboo (Phyllostachys pubescens). Journal of Wood Science 59(2): 155-159.

35. Tanaka A, Zhu Q Tan H, Horiba H, Ohnuki K (2014) Biological activities and phytochemical profiles of extracts from different parts of bamboo (Phyllostachys pubescens). Molecules (Basel, Switzerland) 19(6): 82388260.

36. Mishra R, Behera BK, Pal BP (2011) Novelty of bamboo fabric. Journal of the Textile Institute 103(3): 1-329.

37. Afrin T, Kanwar RK, Wang X, Tsuzuki T (2014) Properties of bamboo fibres produced using an environmentally benign method. The Journal of the Textile Institute 105(12): 1293-1299.

38. Afrin T, Tsuzuki T, Kanwar RK, Wang X (2012) The origin of the antibacterial property of bamboo. Journal of the Textile Institute 103(8): 844-849.

39. Chen JH, Wang K, Xu F, Sun RC (2015) Effect of hemicellulose removal on the structural and mechanical properties of regenerated fibers from bamboo. Cellulose 22(1): 63-72.

ISSN: 2574-1241

DOI: $10.26717 /$ BJSTR.2020.32.005309

N Gokarneshan. Biomed J Sci \& Tech Res

(C) This work is licensed under Creative

Submission Link: https://biomedres.us/submit-manuscript.php
40. Waite M (2009) Sustainable textiles: The role of bamboo and a comparison of bamboo textile properties. Journal of Textile and Apparel, Technology and Management 6(2): 1-21.

41.Zupin Z, Dimitrovski K (2010) Mechanical properties of fabrics made from cotton and biodegradable yarns bamboo, SPF, PLA in weft. In Woven fabric engineering pp. 25-46.

42. Bahrum Prang Rocky, Amanda J Thompson (2020) Investigation and comparison of antibacterial property of bamboo plants, natural bamboo fibers and commercial bamboo viscose textiles. The Journal of The Textile Institute.

43. Xing Shengyuan, Liu Zheng (2004) The performance and product development of bamboo fiber. China Textile Leader (4): 43-48.

44. Sun Jujuan 2007.

45. Zhou Hengshu, Deng Libin (2005) Study on the function and the antivirus finishing of the original bamboo fabric. Progress in Textile Science \& Technology (5): 12-15.

46. Zhu Liwei, Shi Limin, Jiang Jianxin (2008) Studies on antibacterial properties of the natural bamboo fabric based on FZ/T 73023-2006. Journal of Donghua University 34(4): 401-404.

$\begin{array}{ll}\text { BIOMEDICAL } & \text { Assets of Publishing with us } \\ \text { RESEARCHES } & \text { - Global archiving of articles } \\ & \text { - Immediate, unrestricted online access } \\ & \text { - Rigorous Peer Review Process } \\ \end{array}$

